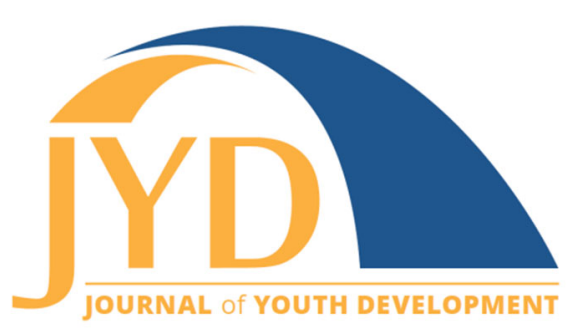

http://jyd.pitt.edu/ | Vol. 15 Issue 5 DOI 10.5195/jyd.2020.996 | ISSN 2325-4017 (online)

\title{
America's Moment: Investing in Positive Youth Development to Transform Youth and Society
}

\author{
Mary E. Arnold \\ National 4-H Council \\ marnold@fourhcouncil.edu
}

\begin{abstract}
As the COVID-19 pandemic wears on, America's youth are suffering in unprecedented ways as their journey to adulthood is interrupted by multiple societal effects. This thought leader piece explores the power of positive youth development in a time of national crisis. The paper outlines the effects of COVID-19 on youths' mental health, educational engagement, and workforce opportunities, all of which have been profoundly affected by the pandemic. The paper makes the case for increasing investment in positive youth development programs and people and highlights key areas where such programs can help support and transform youth, and in-turn society writ large. These areas include increasing equitable access to youth development programs, addressing gaps in opportunities for youth, creating a workforce pipeline, elevating youth voice, and promoting civil discourse and engagement.
\end{abstract}

Key words: positive youth development, COVID-19, youth investment, civic engagement

\section{Introduction}

The world as we know it was turned upside down in early March as the global COVID-19 pandemic descended on the United States. In a matter of weeks states established stay-athome orders for all but essential workers in an attempt to flatten the rising curve of virus cases that threatened to overrun the capacity of the nation's hospitals. Schools were closed, education moved online, youth activities were halted, and families began to cope with the everincreasing negative impacts of the virus on daily life and well-being.

Youth development organizations responded quickly by adapting programs to virtual and noncontact formats, creating educational materials, and determining ways to stay connected with

(cc) EY New articles in this journal are licensed under a Creative Commons Attribution 4.0 License. This journal is published by the University Library System, University of Pittsburgh and is cosponsored by the University of Pittsburgh Press. The Journal of Youth Development is the official peer-reviewed publication of the National Association of Extension 4-H Youth Development Professionals and the National AfterSchool Association. 


\section{America's Moment}

youth and their families. Thought leaders, policy makers, and intermediaries offered an array of webinars to assist youth development practitioners as they navigated the new landscape. Seemingly overnight, the world of youth development changed—or did it? As this paper points out, despite the many changes in the way youth development takes place in a COVID-19 world, the how and why, remain the same. Now, more than ever, positive youth development opportunities for young people in America are urgently needed to address the pandemic's impact on youth, help ensure the success of a generation in peril, and support youth engagement both now and in a post COVID-19 world.

\section{The Impact of COVID-19 on Youth Well-Being}

For many youth COVID-19 will be the defining issue of their lives and affect them in ways that will mark the course of their life-long development (Bartlett \& Virette, 2020). Some are positioning the pandemic as yet another large-scale societal concern that has impacted this generation of young people directly, beginning with the terrorist attacks of 9/11 and continuing alongside such concerns as global climate change, school gun violence, racism, and systemic inequities (Polakovic, 2020).

As young people across the country spend their days at home, practice physical distancing from friends and others who support them, figure out how to stay motivated in school work and other tasks, and deal with the disappointment of lost summer activities, a grim reality is taking shape regarding the impact that these life changes are having on youth. The well-being of our nation's young people is in danger as a tidal wave of trauma and its aftermath approaches (Margolis et al., 2020). This is especially so for youth who were vulnerable before the pandemic (Cohen \& Bosk, 2020).

As summer turns to autumn, and the country struggles with if and how to open schools and youth programs amidst infection rates of COVID-19 that rose during the summer, evidence continues to underscore the importance of schools and programs in facilitating the social, emotional, and cognitive well-being of children and adolescents. The balancing act is how to keep students, teachers, staff, and their families safe, while attending to the critical developmental needs of youth.

While the full effects have yet to be realized, one thing we know for sure is that children and adolescents are at particular risk for negative psycho-social effects of the pandemic (Liang et 


\section{America's Moment}

al., 2020; National 4-H Council, 2020; Nobles et al., 2020). COVID-19 is bringing to high relief, and even accelerating, the social inequities present before the pandemic, creating an urgent call to ensure that the most vulnerable of America's children are not left even further behind (Afterschool Alliance, April 2020). In the face of multiple societal impacts of the virus the current disruption in the journey to adulthood caused by COVID-19 places young people at risk for not having their critical developmental needs met. The enormity of the COVID-19 crisis presents the biggest test to date of the ability of young people to bounce back. Of particular concern is the impact of the pandemic on youth mental health, education, and workforce and career opportunities.

\section{Youth Mental Health}

As noted by public health researcher Ezra Golberstein, children's mental health deteriorates with economic downturns, and with the compounding effects of COVID-19, the impact on youth mental health is going to be pronounced (Kluger, 2020). Research from China, the epicenter of the pandemic revealed that COVID-19 has had a marked effect on the mental health of Chinese youth (Liang et al., 2020). In Italy, another virus hotspot, concerted efforts are being made to protect children from the effects of potential post-traumatic stress disorder (PTSD) related to COVID-19 (Roccella, 2020). The full effect of the COVID-19 pandemic on youth mental health in the United States is still unclear, but the potential for widespread socio-emotional distress is great (Cantor, 2020). A dawning recognition of the effects of the pandemic on youth is taking place across the country, and many are calling for action to ensure that schools and out-ofschool-time organizations are prepared to meet the needs of distressed youth as they return to school and programs that serve them (American Psychiatric Association, 2020; Golberstein et al., 2020.)

A recent survey of over 1500 youth conducted by National 4-H Council (2020) revealed alarming statistics for youth mental health. Key findings showed that over $81 \%$ of youth indicate mental health is a significant issue for young people in the United States, $71 \%$ say their schoolwork makes them feel anxious or depressed, and almost half report feeling excessive stress and depression. Eighty-two percent of the youth are calling on America to talk more openly about mental health issues. As the COVID-19 pandemic wears on, youth in the survey report spending 9 hours a day on screen devices. At the same time America's Promise Alliance reports that while $92 \%$ of teens were engaged in online learning opportunities, most (78\%) spent 4 or fewer hours in class or working on assignments (Margolis et al., 2020). The same 


\section{America's Moment}

survey revealed that $30 \%$ of young people report they have been more unhappy or depressed, and nearly the same number report worrying about having their basic needs met

The stress of the pandemic is overwhelming for many families. Parents are unable to be a buffer of stress for their children due to their own financial concerns, worry, and social isolation as they struggle to provide and care for their children's basic needs (Yoshikawa et al., 2020). Furthermore, racial inequities affect a family's ability to cope with stress, especially during the severe economic upheaval of recent months. African-American families, for example, have one tenth of the net worth of white families, even with similar levels of education, leaving them more vulnerable economically (Traub et al., 2017). Such statistics reveal the precarious nature of many families to weather severe economic distress, and the potential resulting impact on a family's ability to buffer stress for children. Of particular concern are the increasing rates of domestic violence in the United States and other countries experiencing stay-at-home orders because of the pandemic. At the same time, reports of child abuse are going down, most likely due to reduced opportunities to spot child abuse or neglect as children are isolated at home, without interaction with teachers and other non-familial adults who ordinarily would identify and report concerns of child abuse and neglect (Campbell, 2020).

COVID-19 highlights the need to understand the effects of adversity, stress, and trauma on young people, not only in this time of pandemic, but as a permanent part of the positive approach to youth development (Lerner et al., 2019). Adversity, which refers to the events in a young person's life that cause stress, does not necessarily lead to trauma. Trauma, on the other hand, results when a person's internal capacity to cope with stress is overwhelmed, or in the face of relentless stress (also called toxic stress) from which a young person has no relief. The impact of trauma and its resulting epigenetic and neural effects on youth has been welldocumented in recent years, particularly when it occurs at key developmental moments in a young person's journey to adulthood (Cantor et al., 2019). Beyond trauma, the effects of isolation and loss of daily routines also have implications for youth mental health (Lee, 2020). Given that most mental health disorders begin in childhood, they pose important threats to the health and well-being of children and adolescents, particularly if left untreated (Golberstein et al., 2020).

Fortunately, research shows remarkable youth resilience in the face of stress and trauma if provided enough resources and support (Margolis et al., 2020), particularly when stress can be buffered by the presence of caregiving adults and supportive environments that provide 


\section{America's Moment}

developmental experiences that support youth thriving (Ludy-Dobson \& Perry, 2010). Fostering and sustaining developmental relationships with youth is a hallmark of positive youth development (Li \& Julian, 2012), and an aspect of youth development practice that should be emphasized at this moment in time (Arnold \& Rennekamp, 2020).

\section{Education}

The impact of the pandemic on academic learning, skill development, and learning loss is still being determined in light of the unprecedented movement from classroom to remote learning. Early estimates are that students will lose about $30 \%$ of the reading gains, and over $50 \%$ of the math skills they learned in the first 7 months of the 2019-20 school year, before the move to remote education (Kuhfeld \& Tarasawa, 2020). While the pivot to online education was remarkably swift and made with the noble intent to continue education without interruption, the evidence shows that the move to distance learning was far from successful nor equitable (Slavin \& Storey, 2020), at least initially. All of these effects are magnified for youth who were experiencing trauma, systemic social inequity, and other disadvantages prior to the pandemic.

For example, relying on remote learning and online classes has exposed deep digital divides, revealing that too many American children live without essential Internet services (Anderson \& Perrin, 2020). This is especially true in rural areas and lower-income neighborhoods. In addition, Black and Latino households have less broadband access than most White households (Pew Research Center, 2019), and are more likely to rely on mobile devices for access rather than computers (Fishbane \& Tomer, 2020). Children at risk academically could be further disadvantaged if they do not have parents who can support their learning process at home (Yoshikawa et al., 2020).

What we do understand is that online education is not a permanent answer. Parents are not prepared to be teachers, and parents are facing their own stress related to the impact of the virus on their lives, often with little time or energy left to also address the educational needs of their children (Mandel, 2020). As schools scramble to figure out opening plans for fall, researchers predict a wave of students returning with elevated student needs, including the traumatic effects of the virus (Halladay Goldman et al., 2020). The social, emotional, and cognitive needs of children returning to school will be a priority, for as Cantor (2020) points out learning can happen only when one has a "calm brain." For students impacted by worry, stress and trauma due to the virus, learning may be difficult if not impossible. More than ever, a whole 


\section{America's Moment}

child approach to learning will be required if youth are to benefit from formal learning (Cantor et al., 2019).

As schools elevate the social, emotional and cognitive needs of students, they will not be able to do this alone (Education Now, 2020). Collaborations with out-of-school time providers to support the developmental needs of youth, as well as formal learning, will be required. More than ever schools will be called on to operate as places of care, support, and connection first, before formal learning can happen (Education Now, 2020).

In the new school context, youth development professionals will play an important supportive role alongside formal education to support student socio-emotional needs and enhance learning through structured, transformative opportunities for learning. One of the key roles that youth development professionals will play is serving as a youth mentor (as distinct from a teacher who evaluates learning). In this role, PYD professionals can develop deeper relationships with young people, supporting both their academic and non-academic interests and activities, while encouraging growth and skill development (Noam \& Bernstein, 2013). Additionally, PYD professionals working in school-based out-of-school-time (OST) programs are often more closely connected to the young person's home life, and can provide information to teachers to help the teacher support the emotional wellbeing of the child (Noam \& Bernstein, 2013), something that will be especially important as schools and communities navigate the effects of COVID-19 on youths' school engagement and success.

The need for increased student and family support in schools, the potential for youth development professionals to collaborate more closely with schools and families, the need to address the systemic educational inequities for youth exacerbated by the virus, and the moral imperative to close the opportunity gap, all lead to a need for a new way of supporting youth learning and development. The whole child approach, brought forth by the consensus research in the sciences of learning and development (Cantor et al., 2019; SoLD Alliance, 2020) has underscored the need to approach youth learning and development through an idiopathic lens that considers the multiple contexts, experiences, strengths, and adversities a child brings to a learning environment. The SoLD research, though primarily focused on reforming K-12 education, holds great promise and value for PYD practice (Lerner et al., 2019), perhaps now more than ever. 


\section{America's Moment}

\section{Youth Employment and Workforce Development}

The pandemic has erased many of the youth employment and other workforce-related opportunities, such as internships and apprenticeship programs that serve as important stepping-stones to career entry. Besides the loss of income, especially through summer and after-school jobs, unemployment can have negative effects on the psychological, economic, and social well-being of individuals and communities, including youth (Blustein et al., 2020). In addition to the immediate economic impacts, youth unemployment has long-term societal costs. Entering the labor market in a recession can lead to dramatic and persistent earnings losses for young people that last their entire career, and the effects of COVID-19 could last for decades, as a generation waits in the wings for opportunities for economic success (Puerto \& Kim, 2020). COVID-19 has exposed and exacerbated the existing inequalities in the labor market leading to a growing gap in employment opportunity, as historically marginalized communities are disproportionately affected in employment opportunities and stable employment during this time (Blustein et al., 2020).

As high school students struggle to find part-time jobs, and recent college graduates move back in with their parents rather than entering the workforce, there is a growing concern not just of the long-term financial and economic health of youth, but for their long-term physical health. Recent research that followed cohorts of youth who came of age in the recession of the early 1980s revealed that cohort suffered increased mortality rates in their 30s; a mortality rate that got stronger as the cohort moved through their 50s (Schwandt \& von Wachter, 2020). There is additional evidence that youth are internalizing the lack of employment opportunities, blaming themselves for failing to find employment, even though they know the lack of opportunity is not their fault (Pinsker, 2020), raising concerns for the impact of unemployment on youth mental, in addition to physical, health.

Despite the worrisome indicators that the road ahead looks rough for young people, the pandemic and calls for social and racial justice are opportunities to elevate the need to support young people in America. The hope for America right now is the chance to emphasize why support for the positive development of youth is necessary and good for all of society, and to lift up youth voice, allowing young people to be part of the solution to the problems that have defined their coming of age. An investment in positive youth development, with its focus on building youth assets, opportunities, and voice through strengths-based programming, will be a critical support for young people as they navigate the significant social turmoil of these times. 
America's Moment

\section{The Positive Youth Development Approach}

Until the early 1990s youth services were largely focused on interventions for problems, such as teen smoking, pregnancy and substance abuse. Scholars and policy makers, however, pushed the public to view youth not as problems to be solved, but young talent to be developed, talent that requires supports and opportunities to become successful, productive, and engaged adult citizens (Benson \& Pittman, 2001). In the past 30 years both the scholarly inquiry and community practice of youth development have blossomed, recognizing that these out-of-school (OST) efforts are an important part of the contextual make-up of young people's daily lives, and an underutilized key to youth success.

Positive youth development (PYD), has been defined as (a) a natural process of development, (b) a philosophy or approach to youth programming, and (c) the outcome of youth programming (Hamilton, 1999). PYD is based on ecological systems understanding that youth grow and development in multiple contexts: family, school, neighborhoods, communities, and other social settings (Damon, 2004). By focusing on a purposeful approach to youth development in OST programs, which is Hamilton's second definition of PYD, we are able to influence both the natural process of development in a positive way and ensure that PYD outcomes are more likely to occur (the first and third points in Hamilton's definition).

Burgeoning research into the process of PYD and its effect on youth, led in part by the National 4-H Study of Youth Development, has established the importance of PYD programs as a rich context for youth (Bowers et al, 2015). PYD programs provide opportunities for young people to develop necessary technical and social, emotional, and cognitive skills; experience supportive relationships with adults; and participate in authentic leadership opportunities (Lerner \& Lerner, 2013). When PYD programs are intentionally designed and conducted following research-based youth development program principles (Eccles \& Gootman, 2002), youth are provided what they need to grow into productive, healthy, and civically engaged young adults (Lerner, Dowling, \& Anderson, 2003).

The 4-H Study of Youth Development provided convincing, systematic evidence that PYD programs promote desirable, definable, and quantifiable qualities of youth, and that youth become more engaged in their communities when they flourish in PYD programs (Bowers et al., 2015; Lerner \& Lerner, 2013). As a result, policies and programs that focus on promoting youth strengths and assets, not just diminishing problems, have increasingly defined the successful and effective approaches to youth development in the past 20 years. 
Today, in the face of the global COVID-19 pandemic America is facing what Dr. Paul Reville, the Francis Keppel Professor of Educational Policy and Administration at the Harvard Graduate School of Education called our "Sputnik Moment," a moment where we as a country fully recognize that a generation of young people are going to be lost, their talent and contributions unrealized, and their future success jeopardized unless we rally as a country and gain the public and political will and understanding that it is in the best interest of everyone to ensure the health, positive development, and education of all young people in America (Education Now, 2020). Indeed, now is America's moment to invest in PYD.

\section{A Call for Investment in Positive Youth Development}

Despite the evidence for the efficacy and impact of PYD approaches and programs, the investments necessary to realize PYD's full potential impact on youth have been neither equitable nor in alignment with the need-and our current crisis is amplifying that need. The history of public investments in youth development in America is astonishingly dismal. One effort, although inconsistent and ever-evolving, is in workforce development that began in the 1930s through the Civilian Conservation Corp (CCC), and later targeted more directly at youth in the 1960s through the Jobs Corp program. Even later investment was made though the workforce investment boards of the 1990s, culminating most recently in the America Recovery and Reinvestment Act (ARRA) in 2009 designed to address the 60-year record high of youth unemployment following the great recession of 2008. Evaluation of the ARRA investment revealed that youth gained real-life, valuable work experience and skills that increased their human capital and long-term job prospects (Ferber \& Sileo, 2019).

Currently, federal funding for youth programs is spread across 21 agencies that provide services and support for youth. The only federal funding source designated exclusively for local OST and summer programs is the $21^{\text {st }}$ Century Community Learning Centers ( $21^{\text {st }}$ CCLC) program that serves nearly 2 million youth and is dispersed through formula grants to state education agencies (Afterschool Alliance, n.d.). The success of $21^{\text {st }}$ CCLC programs is well documented, but the demand for programs outweighs availability, with only one in three families who want after-school programs for their children having access (Afterschool Alliance, March 2020).

The call for robust investment in America's youth has been a constant plea across the youth development field for some time. Newman et al. (2001) stated in their analysis of the real 


\section{America's Moment}

investment needed to ensure youth success that we cannot say youth are truly a priority until we are willing to fund what is needed to ensure youth have the programs and support they need for success. Furthermore, they argue that the health of our entire nation and its economy relies on youth success, that funding needs to match the level of any other major societal investment, and that such funding should not be borne by only one segment of the population (Newman et al., 2001).

As the United States faces the great social and economic impacts of COVID-19, the magnification of its effects for people of color are laid bare. The structural and systemic barriers to success for young people of color, brought to the public square through the Black Lives Matter movement, highlight again that the most vulnerable youth need the greatest investment, promoting calls for equity that can no longer be ignored. Investing in young people of color and addressing the barriers that keep them from prosperity is fiscally and socially responsible (Bird, 2016). In the face of the pandemic and ongoing calls for social justice, such investment is also our country's moral obligation.

According to the United Nations (n.d.), investing in youth is not only smart, doing so recognizes that youth success is critical to a nation's society, economy and democracy. Failure to invest in youth triggers substantial social problems, leading to negative youth outcomes. Some of these negative outcomes are surely to increase because of COVID-19, such as lack of workforce opportunity and entry, school disengagement, poor mental health, violence, and substance abuse. Furthermore, the United Nations notes that economic shocks, such as the one we are currently experiencing can impact healthy adolescent development and requires targeted programs and policies to prevent negative long-term consequences. Without enhanced investment in youth development approaches, we are a nation at risk of losing large proportions of youth to the negative effects of the pandemic. We are also at risk of forgetting that youth develop optimally in the context of healthy families, communities, and schools as well as the daily people, programs, opportunities, and experiences those contexts provide. It is these opportunities and experiences, and the people who make them happen, that are so critical to supporting and enhancing young people's learning and development.

As families and communities struggle in the face of COVID-19, as historically marginalized families and youth take an inequitable proportion of the pandemic's fallout amid systemic injustice, youth development programs that provide an intentional context to buffer youth and support their healthy growth and development are more critical than ever. Unfortunately, just 


\section{America's Moment}

as the need for youth development programming is escalating, the future of such PYD programming is at risk. According to a recent survey of after-school programs, $84 \%$ of providers are concerned they will not be able to provide services this fall. Sixty-one percent are concerned they will have to close their programs permanently (Afterschool Alliance, July 2020). This is indeed our Sputnik moment, the moment when we are sufficiently alarmed as a country that we take action and make critical investments. Alarmed that we are at risk of losing the enormous potential contributions of a whole generation-to instead find one that is marked by hopelessness, a gradual devolution into despair, disengagement, and disinterest in a democracy and society that was not there for them in this moment of national crisis-we can and must be there for America's young people.

\section{The Power of Positive Youth Development to Transform Youth and Society}

PYD is based on the premise that young people grow and thrive through mutual and positive interactions with the contexts of their daily lives (Lerner et al., 2015). The contexts of a young person's life, including school, neighborhood socializing, sports, clubs, and other social activities have all but disappeared in light of COVID-19. And one of the biggest aspects of these contexts, relationships with caring adults have been dramatically altered, or eliminated altogether, leaving young people without the critical support they need to buffer and navigate this new world. A PYD approach is required to address and mitigate COVID-19 impacts on youth by providing youth a place to belong, access to supportive mentoring relationships with adults, and opportunities for authentic youth leadership and youth voice (Lerner \& Lerner, 2013). Unlike direct interventions for specific problems (e.g., mental health services and hunger reduction) a PYD approach addresses the social, emotional, and cognitive development of the "whole child." This whole-child approach is more critical than ever because of the deep impact of the COVID19 event on multiple contexts of youths' lives.

The PYD approach creates "powerful pathways" for youth (Pittman, 2017, p. 1172) that increase the likelihood and change the odds of a successful transition to adulthood, despite the times. PYD supports the positive functioning of all youth, ensuring every young person is prepared and ready to face the challenges that lie ahead (Pittman, 2017). Critical to the success of the PYD approach is the intentional elevation of youth voice and youth engagement in understanding the experience of COVID-19 on their lives (Efuribe et al., 2020). PYD programs help to ensure that youth are equipped and empowered to navigate the societal concerns currently brought to high relief in this country. The concerns include the widening opportunity 


\section{America's Moment}

gap, deteriorating youth mental health, and reduced workforce development opportunities, all of which are further impacted by racial and systemic inequities, a breakdown in civil discourse, and diminishing civic engagement.

Closing the Opportunity Gap - The pandemic has in many ways dramatically illuminated and forced the issue of addressing the opportunity gap. As noted by Levinson (2020) the COVID-19 pandemic has magnified the sociopolitical and economic drivers of the opportunity gap, but it has not revealed anything new about these inequities. Rather, the pandemic has shifted public awareness and raised the stakes if, as a country, we fail to reduce the opportunity gap. Research has revealed the stark inequities among youth as their promise for success is derailed by social, economic, and structural disadvantages, which often are accompanied by racism, bias, and discrimination (National Academy of Sciences, Engineering, \& Medicine, 2019). However, the move to online education, which required facing and attempting to solve inequities in online access shows that we have had the capacity, if not the will, to address inequities all along (Levinson, 2020).

Young people without fair access to youth development opportunities slip further and further behind, resulting in dramatically different positive outcomes than youth with greater opportunity and access to programs. Negative developmental trajectories lead to poorer long-term health and economic outcomes in adulthood. Research shows, however, that youth engagement in PYD programs can increase school commitment and academic achievement (Jekielek et al., 2002). In addition, while PYD approaches are beneficial to all youth, there is evidence that participation in PYD programs is particularly beneficial to vulnerable and marginalized youth (Eichas et al., 2017; Pittman, 2017).

PYD programs are uniquely positioned to help close the opportunity gap by addressing the youth disparities associated with race, class, and gender, all of which are root causes of inequities in education (Pittman, 2017). When attention is paid to addressing barriers that prevent equitable access to PYD programs and opportunities, PYD programs can provide a level field for youth development. PYD programs provide youth-centered intentional contexts where all youth belong and where youth can connect to adult mentors and have opportunities and experiences that support their social, emotional, and cognitive skill development; education and workforce exploration; and identity development. PYD mentors and peers become allies for young people, ensuring their inclusion, supporting their dreams and goals, standing up against discrimination and bias, providing the enrichment experiences often available only to more 


\section{America's Moment}

privileged youth, and empowering youth voice and action to work against the structures that prevent all youth from succeeding.

In short, PYD programs help youth define and follow their own powerful pathways-pathways that help young people grow successfully from where they are now to where they want to be (Pittman, 2017), and even more critically, to where society needs them to be in order to maximize their generation's contributions.

Strengthening Youth Mental Health - As youth mental health concerns reach epic proportions PYD programs help youth build the resilience they need to navigate the stress of COVID-19 and its impacts on their lives. Of particular importance is the presence of a caring adult who can buffer stress for young people and support their growth and resilience through the formation of developmental relationships (Li \& Julian, 2012; Pekel et al., 2018). PYD programs provide a place for youth to experience psychological and physical safety, belong and matter, develop supportive peer relationships, and experience positive social norms and boundaries (Eccles \& Gootman, 2002), all important ingredients for alleviating youth stress and building resilient mindsets and skills.

Creating a Workforce Pipeline - While the pandemic has reduced access to many of the careerbuilding opportunities for youth, such as summer and after-school jobs, internships and apprenticeships, the skills required for success in the workplace have not changed. Many young people lack the training, education, skills, and opportunities to enter the job market successfully, and building those skills for post-pandemic employment is more important than ever. PYD programs support youth-to-work pipelines by focusing on career development, often in the context of their own communities (Bakshi \& Jahnvee, 2014). PYD also provides a holistic approach to developing the attitudes and skills important to workforce success. PYD supports youth workforce development through positive relationships; improving social, emotional, cognitive and technical skills; linking youth to opportunities; and promoting a sense of youth mattering and worthy contribution, all within a safe and supportive developmental context (Moore et al., 2018). PYD programs can also serve to develop an intentional pathway that leads a young person from nascent interest in a topic to a career, such as STEM programs that promotes science and technology skills, critical thinking, problem solving, and teamwork on a purposeful pathway to careers in a STEM-related field. 


\section{America's Moment}

Civil Discourse for a Fractured World - Rather than unite us in a common effort, the COVID-19 pandemic, set against the recent calls for social justice and addressing systemic racism, has magnified the fractures among us. Today's America is marked by a lack of civil discourse, intolerance, name-calling, blaming of the "other," and arguments over mask wearing and whether the pandemic is even real. As we navigate the effects of COVID-19, we have witnessed societal polarization and a general inability to communicate differences in a productive manner. This lack of civil discourse undermines the very foundations of our freedom, allowing fear and hatred to gain momentum. In short, the breakdown of civil discourse is an imminent threat to our democracy as the nation grapples with the pandemic and elevates insistence to address racism, inequity, and systemic injustice.

Built on the principle of inclusion and belonging, PYD programs provide spaces for young people to explore, understand and appreciate diversity, and to develop the interpersonal skills to navigate differences in productive and civil ways. PYD promotes the development of important problem-solving and teamwork skills, as well as active listening skills, empathy, and connection with others.

Civic Contribution and Engagement- Perhaps more now than ever, America needs the thoughtful, committed engagement of its citizens, engagement that has the power to transform current civic strife into real and lasting change. If the current American landscape shows us anything, it is that the ruptures caused by the pandemic and social unrest have laid before us hope and possibility of real, lasting change. As the leaders of today leave public service behind, a pipeline of young people must be prepared to step into leadership roles at all levels, and they must be prepared to lead with new skills that work to unite, rather than divide. PYD programs develop youth understanding of democratic principles and processes and provide real-life opportunities for youth to serve in authentic leadership roles as a key aspect of PYD (Lerner et al., 2003).

PYD programs emphasize civic engagement from an early age through volunteerism and other community contributions. Youth of all ages are engaged in their communities, learning to navigate power structures in local governments and agencies; developing knowledge of democratic principles and civil rules of order; and participating in hands-on learning leadership experiences at the local, state, and federal levels. Participation in PYD programs leads to young people who care about others and give back to their communities through volunteerism, leadership, and civic engagement (Lerner \& Lerner, 2013). 


\section{America's Moment}

Elevating Youth Voice - Supporting youth in developing their own voice and providing a platform for those voices to be heard is a long-established emphasis in youth development practice. Although presented last in the list of PYD solutions, the elevation of youth voice should be woven throughout all aspects of PYD. As this generation of young people confronts yet another societal event that marks their youth and will dramatically impact their coming of age, youth have a right to express their voice, to share their experience, and to be part of the decisions and solutions that affect them (Blustein et al., 2020). As Efuribe et al. (2020) state in their commentary on coping with COVID-19: "let's not wait for adolescents and young adults to protest for their voices to be heard" (p. 17). Rather, let's look back on this time, a time like no other, and remember how youth voices were powerfully elevated-when the opportunity gap began to close, when youth mental health improved, when civil discourse began to flourish, and when youth voice was mobilized to lead America forward.

\section{CONCLUSION}

As of this writing, state-by-state the country is struggling with whether, when, and how to lift many stay-at-home orders, and cautiously attempting to resume social interactions in ways that help keep the virus at bay, even while it still lives strongly amongst us. Youth are beginning to emerge from isolation to take part in modified versions of the social interactions and activities that provide the contexts for healthy development. As a country, we are struggling with what level of risk the virus poses and to whom and working out a balance of personal freedom and collective responsibility as we settle into co-existence with COVID-19 for the foreseeable future.

Youth development organizations and programs are also emerging from initial reactions, the swift pivoting of programs to virtual and non-contact versions, and adapting summer programs. As we turn the corner and figure out what back-to-school even looks like this fall, youth development organizations are focusing on the path forward into the unknown. For the 4-H Youth Development Program, we are moving from a place of immediate reaction, and now rebounding as we begin to re-imagine a 4-H program for the future. Exactly what that reimagined 4- $\mathrm{H}$ program looks like is still to be determined, but there is increasing evidence that 4-H professionals and volunteers are going to need new training and support as they turn to a whole-child approach and more virtual and non-contact ways to support the positive development of youth. 
In their recent commentary on PYD and the COVID-19 pandemic, Ettekal and Agans (2020) stated the importance of youth-serving organizations to stay true to their program theory of change. Even though program activities and delivery may look different in the future, the basic theory of PYD-providing youth safe and structured contexts, where belonging and mattering are emphasized, that foster developmental relationships with caring adults and provide skillbuilding opportunities; promote social, emotional, \& cognitive development; and elevate youth voice for authentic leadership-is the bedrock beneath the path forward.

\section{References}

Afterschool Alliance. (2020, March). 21 ${ }^{\text {st }}$ Century community learning centers: Inspiring learning. Supporting families. Earning results. Author. http://afterschoolalliance.org//documents/21stCCLCOverview.pdf

Afterschool Alliance. (2020, April 7). Facing inequity with youth and families during the COVID-19 era [Webinar]. Author. http://www.afterschoolalliance.org/webinars.cfm?ID=904B7C7E-5056-A82E7AF937731EB50A07

Afterschool Alliance. (2020, July). Afterschool in the time of COVID-19. Author.

http://afterschoolalliance.org/documents/Afterschool-COVID-19-Wave-1-Fact-Sheet.pdf

Afterschool Alliance. (n.d.). $21^{\text {st }}$ CCLC is a critical source of funding for many local afterschool and summer learning programs. Author. http://www. afterschoolalliance.org/policy21stcclc.cfm

American Psychiatric Association. (2020, July 15). Needs of students during the COVID-19 era: American Academy of Child and Adolescent Psychiatry (AACAP) and American Psychiatric Association (APA) detail steps necessary for safely reopening school this fall.

https://www.psychiatry.org/newsroom/news-releases/needs-of-students-during-the-covid-19-eraamerican-academy-of-child-and-adolescent-psychiatry-aacap-and-american-psychiatricassociation-apa-detail-steps-necessary-for-safely-reopening-schools-this-fall

Anderson, M., \& Perrin, A. (2020). Nearly one-in-five teens can't always finish their homework because of the digital divide. Pew Research Center. https://www.pewresearch.org/facttank/2018/10/26/nearly-one-in-five-teens-cant-always-finish-their-homework-because-of-thedigital-divide/

Arnold, M. E., \& Rennekamp, R. A. (2020). A time like no other: 4-H Youth Development and COVID-19. Journal of Extension, 58(3). https://joe.org/joe/2020june/comm1.php

Bakshi, A. J., \& Jahnvee, J. (2014). The interface between positive youth development and youth career development: New avenues for career guidance practice. In In G. Arulmani, A. J. Bakshi, F. T. L. Leong, \& A. G. Watts (Eds.), International and cultural psychology. Handbook of career 
development: International perspectives (p. 173-201). Springer. https://doi.org/10.1007/978-14614-9460-7 10

Bartlett, J. D., \& Virette, R. (2020). Ways to promote children's resilience to the COVID-19 pandemic. Child Trends. https://www. childtrends.org/wpcontent/uploads/2020/04/COVIDProtectiveFactors ChildTrends April2020.pdf

Bird, K. (2016). Realizing youth justice: advancing education and employment through public policy and investment. Center for Law and Social Policy. https://eric.ed.gov/?id=ED568163

Benson, P., \& Pittman, K. (2001). Moving the youth development message: Turning a vague idea into a moral imperative. In P. L. Benson \& K. J. Pittman (Eds.). Trends in youth development: Visions, realities and challenges (pp. vii-xii). Kluwer Academic Publishers.

Blustein, D. L., Duffy, R. Ferreira, J. A., Cohen-Scali, V., Cinamon, R. G., \& Allan, B. A. (2020). Unemployment in a time of COVID-19: A research agenda. Journal of Vocational Behavior, 119. https://doi.org/10.1016/j.jvb.2020.103436

Bowers, E. P., Geldhof, G. J., Johnson, S. K., Hilliard, L. J., Hershberg, R. M., Lerner, J. V., \& Lerner, R. M. (2015). Applying research about adolescences in real-world settings; The sample case of the 4-H study of positive youth development. In E. P. Bowers, G. J. Geldhof, S. K. Johnson, L.J. Hilliarn, R. M Hershberg, J. V. Lerner, \& R. M. Lerner (Eds.), Promoting Positive Youth Development: Lessons from the 4-H Study, pp. 1-18. Springer.

Cantor, P. (2020, March 13). Coronavirus: Keeping our children and ourselves safe [Audio podcast]. https://www.turnaroundusa.org/the-180-podcast-coronavirus/

Cantor, P., Osher, D., Berg, J., Steyer, L., \& Rose, T. (2019). Malleability, plasticity and individuality: How children learn and develop in context. Journal of Applied Developmental Science, 23(4), 307-337. https://doi.org/10.1080/10888691.2017.1398649

Campbell, A. M. (2020). An increasing risk of family violence during the COVID-19 pandemic: Strengthening community collaborations to save lives. Forensic Science International: Reports, 2, 100089. https://doi.org/10.1016/j.fsir.2020.100089

Cohen, R. I. S., \& Bosk, E. A. (2020). Vulnerable youth and the COVID-19 pandemic. Pediatrics, 146(1) no. e20201306. https://doi.org/10.1542/peds.2020-1306

Damon, W. (2004). What is positive youth development? The Annual of the American Academy of Political and Social Science, 591(1), 13-24.

Eccles, J., \& Gootman, J. (Eds.). (2002). Community programs to promote youth development. National Academy Press.

Education Now| Harvard Graduate School of Education. (May 20, 2020). The path forward [Video]. YouTube. https://www.youtube.com/watch?v=xN1QKjKvTIs\&t=46s 
Eichas, K., Montgomery, M. J., Meca, A., \& Kurtines, W. M. (2017). Empowering marginalized youth: A self-transformative intervention for promoting positive youth development. Child Development, 88(4), 1115-1124. https://doi.org/0.1111/cdev.12866

Efuribe, C., Barre-Hemingway, M., Vaghefi, E., \& Ballonoff Suleiman, A. (2020). Coping with COVID-19: A call for engagement and inclusion of young people in matters that affect their lives. Journal of Adolescent Health, 67, 16-17. https://doi.org/10.1016/j.jadohealth.2020.04.009

Ettekal, A. \& Agans, J. P. (2019). Positive youth development through leisure: Confronting the COVID-19 pandemic. Journal of Youth Development, 15(2), 1-20. https://doi.org/10.5195/jyd.2020.962

Ferber, T, \& Sileo, A. (2019). The workforce investment and opportunity act: Investments in youth work experiences: A case study on using evidence for improvement. The Forum for Youth Investment. https://forumfyi.org/knowledge-center/wioa-case-study/

Fishbane, L. \& Tomer, A. (2020, March 20). As classes move online during COVID-19, what are disconnected students to do? Brookings Institute. https://www.brookings.edu/blog/theavenue/2020/03/20/as-classes-move-online-during-covid-19-what-are-disconnected-students-todo/

Golberstein, E., Wen, H., \& Miller, B. F. (2020). Coronavirus disease 2019 (COVID-19) and mental health for children and adolescents. Journal of the American Medical Association-Pediatrics. https://doi.org/10.1001/jamapediatrics.2020.1456

Halladay Goldman, J., Danna, I., Maze, J. W., Pickens, I. B., \& Ake III, G. S. (2020). Trauma informed school strategies during COVID-19. National Center for Child Traumatic Stress. https://www.nctsn.org/resources/trauma-informed-school-strategies-during-covid-19

Hamilton, S. (1999). A three-part definition of youth development. [Unpublished manuscript]. Cornell University College of Human Ecology.

Jekielek, M. A., Moore, K. A., Hair, E. C., \& Scarupa, H. J. (2002). Mentoring: A positive strategy for youth development. Child Trends. https://www.childtrends.org/wpcontent/uploads/2002/02/MentoringRB.pdf

Kluger, J. (2020, August 3). The Coronavirus Seems to Spare Most Kids From Illness, but Its Effect on Their Mental Health Is Deepening. Time Magazine. https://time.com/5870478/children-mentalhealth-coronavirus/

Kuhfeld, M., \& Tarasawa, B. (2020). The COVID-19 slide: What summer learning loss can tell us about the potential impact of school closures on student academic achievement. NWEA Research. Available at: https://www.nwea.org/research/publication/the-covid-19-slide-what-summerlearning-loss-can-tell-us-about-the-potential-impact-of-school-closures-on-student-academicachievement/ 
America's Moment

Lee, J. (2020). Mental health effects of school closures during COVID-19. The Lancet, 4, 421. https://doi.org/10.1016/S2352-4642(20)30109-7

Lerner, R. M., Dowling, E. M., \& Anderson, P. M. (2003). Positive youth development: Thriving as the basis of personhood and civil society. Applied Developmental Science, 73$), 172-180$. https://doi.org/10.1207/S1532480XADS0703 8

Lerner, R. M., Geldhof, G. J., \& Bowers, E. P. (2019). The science of learning and development: Entering a new frontier of human development theory, research, and application. Journal of Applied Developmental Science, 23(4), 305-306. https://doi.org/10.1080/10888691.2019.1630995

Lerner, R. M., \& Lerner, J. V. (2013). The positive development of youth: Comprehensive findings from the 4-H study of positive youth development. National 4-H Council. https://4-h.org/wpcontent/uploads/2016/02/4-H-Study-of-Positive-Youth-Development-Full-Report.pdf

Lerner, R. M., Lerner, J. V., Bowers. E. P., \& Geldhof, J. G. (2015). Positive youth development and relational developmental systems. In R. M. Lerner, W. F. Overton, \& P. C. M. Molenar (Eds.) Handbook of Child Psychology and Developmental Science ( $7^{\text {th }}$ Ed., Volume 1 Theory and Method, pp. $608-651)$. John Wiley and Sons. https://doi.org/10.1002/9781118963418.childpsy116

Levinson, M. (2020). Educational ethics during a pandemic. COVID-19 Rapid Response Impact Initiative White Paper 17.Edmond J. Safra Center for Ethics, Harvard University. https://ethics.harvard.edu/files/center-for-ethics/files/17educationalethics.pdf

Li, J., \& Julian, M. (2012). Developmental relationships as the active ingredients: A unifying working hypothesis of "what works" across intervention settings. American Journal of Orthopsychiatry, 82(2), 157-66. https://doi.org/10.1111/j.1939-0025.2012.01151.x

Liang, L., Ren, H., Cao, R., Hu, Y., Qin, Z., Li, C., \& Mei, S. (2020). The effect of COVID-19 on youth mental health. Psychiatric Quarterly. [On-line pre-press publication]. https://link.springer.com/article/10.1007/s11126-020-09744-3

Ludy-Dobson, C. \& Perry, B. D. (2010). The role of healthy relational interactions in buffering the impact of childhood trauma. In E. Gil (Ed.), Working with children to heal interpersonal trauma (pp. 2644). Guilford Press.

Mandel, B. (2020, April 20). Distance learning isn't working: Instead of trying to move classes online, schools should support parents in educating their children. Atlantic Magazine. https://www.theatlantic.com/ideas/archive/2020/04/just-give-distance-learning/610222/

Margolis, M., Doyle Lynch, A., Pufall Jones, E. \& Hynes, M. (2020). The state of young people during COVID-19: Findings from a nationally representative survey of high school youth. America's Promise Alliance. https://www.americaspromise.org/press-release/national-survey-high-schoolstudents-during-covid-19-finds-widespread-negative-impact 
Journal of Youth Development | http://jyd.pitt.edu/ | Vol. 15 Issue 5 DOI 10.5195/jyd.2020.996

America's Moment

Moore, K. A., Lantos, H., Murphy, K. Redd, Z., \& Beckwith, S. (2018). The PILOT assessment: A guide to integrating positive youth development into workforce training settings. Child Trends. https://www.childtrends.org/wpcontent/uploads/2018/05/PILOTchecklist ChildTrends April2018.pdf

National 4-H Council. (2020). New study finds 7 in 10 teens are struggling with mental health. Author. https://4-h.org/media/new-survey-finds-7-in-10-teens-are-struggling-with-mental-health/

National Academy of Sciences, Engineering, and Medicine. (2019). The promise of adolescence: Realizing opportunity for all youth. National Academies Press. https://www.nap.edu/catalog/25388/thepromise-of-adolescence-realizing-opportunity-for-all-youth

Newman, R. P., Smith, S. M., \& Murphy, R. (2001). A matter of money: The cost and financing of youth development. In P. L. Benson \& K. J. Pittman (Eds.) Trends in youth development: Visions, realities and challenges (pp. 91- 134). Kluwer Academic Publishers.

Noam, G. G., \& Bernstein, B. (2013). Youth development practitioners and their relationships in schools and after-school programs. New Directions for Youth Development, 137, 57-68. https://doi.org/10.1002/yd.20048

Nobles, J., Martin, F., Dawson, S., Moran, P., \& Savoic, J. (2020). The potential impact of COVID-19 on mental health outcomes and the implications for service solutions. National Institute for Health Research: University of Bristol. https://arc-w.nihr.ac.uk/research-and-implementation/covid-19response/reports/potential-impact-of-covid-19-on-mental-health-outcomes-and-the-implicationsfor-service-solutions/

Pekel, K., Roehlkepartain, E. C., Syvertsen, A. K., Scales, P. C., Sullivan, T. K., Sethi, J. (2018). Finding the fluoride: Examining how and why developmental relationships are the active ingredient in interventions that work. American Journal of Orthopsychiatry, 88(5):493-502. https://doi.org/10.1037/ort0000333

Pew Research Center. (2019). Internet/broadband fact sheet. https://www.pewresearch.org/internet/fact-sheet/internet-broadband/

Pittman, K. (2017). Positive youth development as a strategy for addressing readiness and equity: A commentary. Child Development, 88(4), 1172-1174. https://doi.org/10.1111/cdev.12872

Pinsker, J. (2020, May 22). The misfortune of graduating in 2020. Atlantic Magazine. https://www.theatlantic.com/family/archive/2020/05/class-of-2020-graduate-jobs/611917/

Polakovic, G. (2020, April 8). How does coronavirus affect young people's psyches? USC Dornsife. https://dornsife.usc.edu/news/stories/3191/coronavirus-covid-19-pandemic-youth-psyches

Puerto, S., \& Kim, K. (2020, April 15). Young workers will be hit hard by COVID-19's economic fallout. International Labour Organization. https://iloblog.org/2020/04/15/young-workers-will-be-hithard-by-covid-19s-economic-fallout/ 
Journal of Youth Development | http://jyd.pitt.edu/ | Vol. 15 Issue 5 DOI 10.5195/jyd.2020.996

America's Moment

Roccella, M. (2020). Children and Coronavirus infection (COVID19): What to tell children to avoid posttraumatic stress disorder (PTSD). The Open Pediatric Medicine Journal, 10, 1-2. https://doi.org $10.2174 / 1874309902010010001$

Schwandt, H., \& von Wachter, T. M. (2020). Socioeconomic decline and death: Midlife Impacts of graduating in a recession. National Bureau of Economic Research.

http://www.nber.org/papers/w26638.pdf

SoLD Alliance. (2020). Elevating science. Advancing Equity. Transforming education. https://www.soldalliance.org/

Slavin, R. E., \& Storey, N.(2020). The US educational response to the COVID-19 pandemic. Best Evidence of Chinese Education, 5(2), 617-633. https://papers.ssrn.com/sol3/papers.cfm?abstract id=3652585

Traub, A., Sullivan, L., Meshede, T., \& Shapiro, T. (2017). The asset value of whiteness: Understanding the racial wealth gap. Demos. https://www.demos.org/research/asset-value-whitenessunderstanding-racial-wealth-gap

The United Nations. (n.d.). Youth as a smart investment. https://www.un.org/esa/socdev/documents/youth/fact-sheets/youth-smart-investment.pdf

Yoshikawa, H., Wuermli, A. J., Britto, P. R., Dreyer, B., Leckman, J. F., Lye, S. J., Ponguta, L. A., Richter, L. M., \& Stein, A. (2020). Effects of the global COVID-19 pandemic on early childhood development: Short- and long-term risks and mitigating program and policy actions. The Journal of Pediatrics, 223, 188-193. https://doi.org/10.1016/j.jpeds.2020.05.020 